\title{
The complete mitochondrial genome of the citrus red mite Panonychus citri (Acari: Tetranychidae): high genome rearrangement and extremely truncated tRNAs
}

Ming-Long Yuan, Dan-Dan Wei, Bao-Jun Wang, Wei Dou, Jin-Jun Wang*

\begin{abstract}
Background: The family Tetranychidae (Chelicerata: Acari) includes 1200 species, many of which are of agronomic importance. To date, mitochondrial genomes of only two Tetranychidae species have been sequenced, and it has been found that these two mitochondrial genomes are characterized by many unusual features in genome organization and structure such as gene order and nucleotide frequency. The scarcity of available sequence data has greatly impeded evolutionary studies in Acari (mites and ticks). Information on Tetranychidae mitochondrial genomes is quite important for phylogenetic evaluation and population genetics, as well as the molecular evolution of functional genes such as acaricide-resistance genes. In this study, we sequenced the complete mitochondrial genome of Panonychus citri (Family Tetranychidae), a worldwide citrus pest, and provide a comparison to other Acari.

Results: The mitochondrial genome of $P$. citri is a typical circular molecule of 13,077 bp, and contains the complete set of 37 genes that are usually found in metazoans. This is the smallest mitochondrial genome within all sequenced Acari and other Chelicerata, primarily due to the significant size reduction of protein coding genes (PCGs), a large rRNA gene, and the A + T-rich region. The mitochondrial gene order for $P$. citri is the same as those for P. ulmi and Tetranychus urticae, but distinctly different from other Acari by a series of gene translocations and/ or inversions. The majority of the P. citri mitochondrial genome has a high A + T content (85.28\%), which is also reflected by AT-rich codons being used more frequently, but exhibits a positive GC-skew (0.03). The Acari mitochondrial nad 1 exhibits a faster amino acid substitution rate than other genes, and the variation of nucleotide substitution patterns of PCGs is significantly correlated with the $G+C$ content. Most tRNA genes of $P$. citri are extremely truncated and atypical (44-65, $54.1 \pm 4.1 \mathrm{bp})$, lacking either the T- or D-arm, as found in P. ulmi, T. urticae, and other Acariform mites.

Conclusions: The P. citri mitochondrial gene order is markedly different from those of other chelicerates, but is conserved within the family Tetranychidae indicating that high rearrangements have occurred after Tetranychidae diverged from other Acari. Comparative analyses suggest that the genome size, gene order, gene content, codon usage, and base composition are strongly variable among Acari mitochondrial genomes. While extremely small and unusual tRNA genes seem to be common for Acariform mites, further experimental evidence is needed.
\end{abstract}

\footnotetext{
* Correspondence: jiwang7008@yahoo.com

Key Laboratory of Entomology and Pest Control Engineering, College of

Plant Protection, Southwest University, Chongqing 400716, China
} 


\section{Background}

The family Tetranychidae (spider mites) (Chelicerata: Acari) includes 1200 species, many of which are of agronomic importance [1], such as Tetranychus urticae, Panonychus citri, and P. ulmi; the former is a worldwide pest of many plant species including several economically important agricultural crops, while the latter two are important fruit plant (e.g., apple and citrus) pests. Spider mites are often difficult to manage because of their ability to rapidly develop resistance to various acaricides [2]. It has been reported that the resistance of T. urticae to the acaricide bifenazate is highly correlated with the remarkable mutations in the mitochondrial encoded cytochrome b (cob) [3]. In addition, several acaricides, such as acequinocyl, fluacrypyrim [4], and METI-acaricides (mitochondrial electron transfer inhibitors, e.g., fenpyroximate and pyridaben) [5], which are now in widespread use globally, target mitochondrial proteins. Unravelling and comparing mitochondrial genomes of spider mites will not only increase our understanding of the molecular evolution of acaricideresistance genes, but also help to develop new acaricides uniquely targeting mitochondrial genes.

During the last 10 years, arthropod mitochondrial genomes have been extensively sequenced due to the improvements of genomic technologies and the interest in mitochondrial genome organization and evolution [6]. Mitochondrial genome sequences not only contain more information than the shorter sequences of single genes, but also provide larger data sets of genome-level features such as gene rearrangements and RNA secondary structures [6-8]. To date, the complete mitochondrial genomes have been sequenced from 25 Acari species. Among these, 14 species belong to the superorder of Parasitiformes while the remaining 11 species belong to the superorder of Acariformes. Most mitochondrial genomes are about $15 \mathrm{~kb}$ circular molecules and encode 37 genes including 13 protein-coding genes (PCGs), two rRNA genes (rRNAs), and 22 tRNA genes (tRNAs), which is typical of Metazoa [9]. However, the mitochondrial genomes of Leptotrombidium pallidum and Metaseiulus occidentalis possess duplicated genes [10,11], and the mtDNA of the sexual oribatid mite Steganacarus magnus lacks 16 tRNA genes [12]. In addition, gene rearrangement, reverse base composition, and atypical tRNA genes are frequently present in Acari, especially for the Acariformes, such as in the mite genera Leptotrombidium [10,13], and Dermatophagoides [14,15], and also in the mite species P. ulmi and T. urticae [3].

Generally, mitochondrial gene content and gene order are highly conserved at the lower taxonomic rank (i.e. family and genus), but gene content variation and arrangement have reported for the genera Leptotrombidium $[10,13]$ and Dermatophagoides $[14,15]$. In addition, the inference of mite mitochondrial tRNA genes may be extremely difficult and even error prone, especially when comparative data is absent [15]. Thus, more mitochondrial genomes from closely related species will improve the accuracy of annotations for mitochondrial genomes, which will also greatly improve our understanding of molecular evolution and phylogenetic relationships [16-19]. In this study, we sequenced and analyzed the complete mitochondrial genome of the citrus red mite $P$. citri (Family Tetranychidae), an important citrus pest with a worldwide distribution, and provide a comparison to other Acari.

\section{Results and discussion}

\section{Genome content and organization}

The mitochondrial genome of $P$. citri is a typical circular DNA molecule of 13,077 bp in length (GenBank: HM189212, Figure 1, Additional File 1). This genome is only 2 bp larger than that of another $P$. citri strain $(13,075 \mathrm{bp})[20]$ and slightly smaller than those of the same-family species $T$. urticae $(13,103 \mathrm{bp})$ [3] and P. ulmi (13,115 bp) (Additional file 2). To date, the mitochondrial genome of $P$. citri is the smallest within all sequenced Acari and other Chelicerate genomes available in the GenBank (status August 20, 2010). Its relatively small size is primarily due to the significant size reduction of PCGs, $r r n L$, and the putative control region ( $\mathrm{A}+\mathrm{T}$-rich region in arthropods) in comparison with other Acari (Figure 2). The mitochondrial genome of $P$. citri contains all 37 genes (13 PCGs, 22 tRNA genes, and two rRNA genes) which are typically present in metazoan mitochondrial genomes [9]. Among these, 20 genes (seven PCGs, two rRNA genes and 11 tRNA genes) are located on the majority strand (J-strand) and the others on the minority strand (N-strand) (Figure 1, Additional File 1). Gene overlaps have been found at 11 gene junctions and have involved a total of $55 \mathrm{bp}$; the longest overlap (14 bp) exists between trn $V$ and trnI. In addition to the large non-coding region, several small non-coding intergenic spacers are present in the $P$. citri mitochondrial genome and are spread over ten positions, ranging in size from 1 to $16 \mathrm{bp}$.

The largest non-coding region, which presumably functions as the mitochondrial control region, is $57 \mathrm{bp}$ long and is present between $\operatorname{cox} 1$ and nad3 (Figure 1, Additional File 1). This region is completely comprised of adenines and thymines $(\mathrm{A}+\mathrm{T}$-rich region) and is the third smallest among all sequenced mitochondrial genomes within Acari; only those of P. ulmi (55 bp) and T. urticae $(44 \mathrm{bp})$ are slightly smaller (Figure 2$)$. The maximum size difference found in the $\mathrm{A}+\mathrm{T}$-rich regions across all sequenced Acari mitochondrial genomes is $2,756 \mathrm{bp}$, indicating that strong size variation among Acari mitochondrial genomes is significantly 


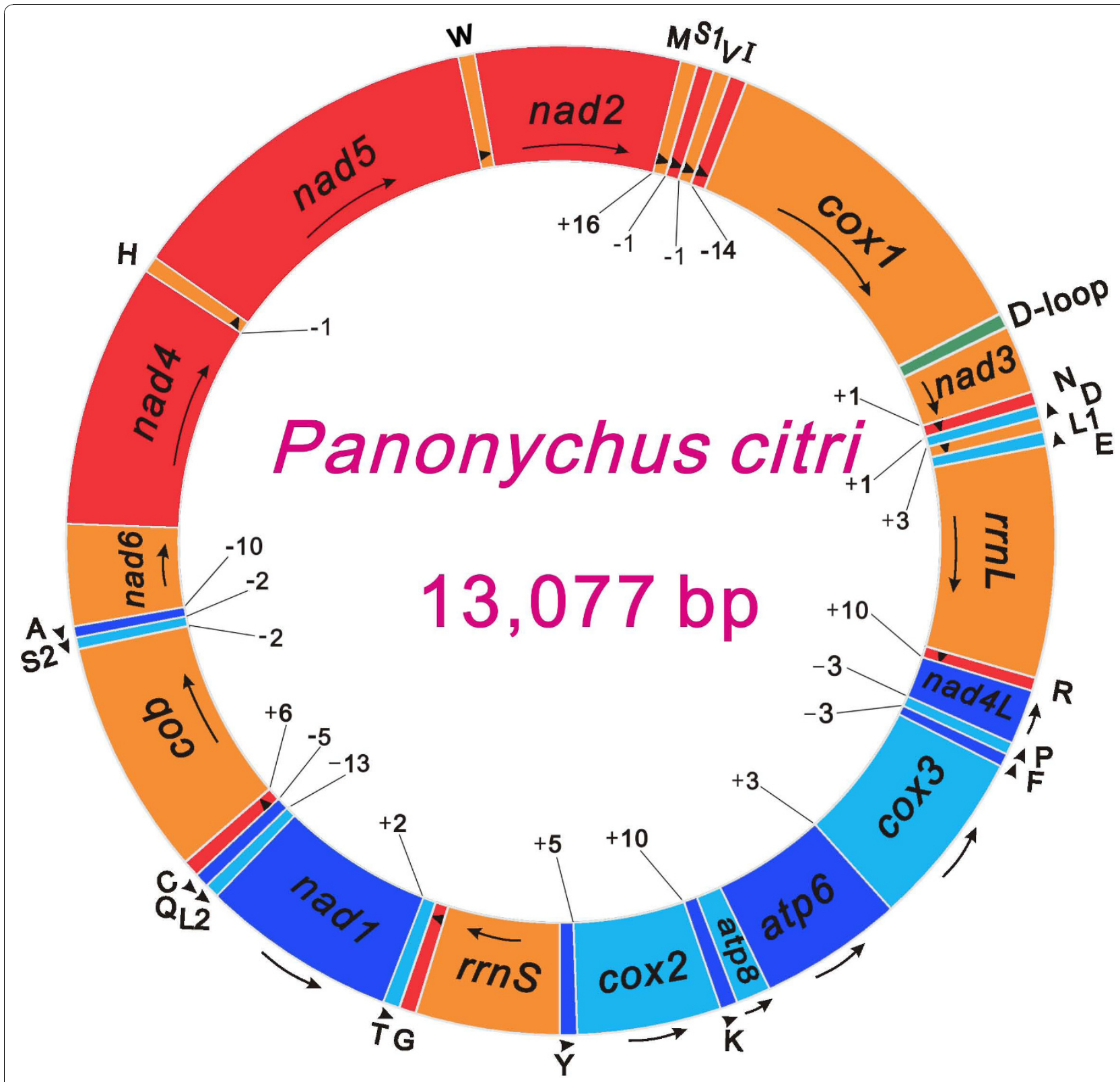

Figure 1 Map of the mitochondrial genome of Panonychus citri. Genes coded in the J-strand (clockwise) are red or orange colored. Genes coded in the N-strand (counterclockwise) are blue or cyan colored. The D-loop (putative control region) is given in green. Alternation of colors was applied for clarity. Protein coding and ribosomal genes are shown with standard abbreviations. Genes for tRNA genes are abbreviated by a single letter, with $S 1=A G N, S 2=U C N, L 1=C U N$, and L2 = UUR. Numbers at gene junctions indicate the length of small non-coding regions where negative numbers indicate overlap between genes.

correlated to the $\mathrm{A}+\mathrm{T}$-rich regions (Figure 2). This result is concordant with previous findings from other chelicerates [21] and insects [22-24]. In fact, the A + Trich region has been identified as the source of size variation in the entire mitochondrial genome, usually due to the presence of a variable copy number of repetitive elements [25]. The relative location of the $\mathrm{A}+\mathrm{T}$-rich region also varies greatly among Acari with the ancestral pattern of arthropods being between $r r n S$ and $\operatorname{trnI}$ [9].
Previous studies of insect $\mathrm{A}+\mathrm{T}$-rich region have identified extensive conserved sequence stretches and hypothetical secondary structure features, which are supposed to be responsible for the control of replication and transcription of the mtDNA [26-29]. In particular, one of the most conserved sequence stretches discovered in hexapod A + T-rich region seems to be an array of thymines ( $\mathrm{T}$-stretches), which are important signalling sites necessary for the initiation of the replication 


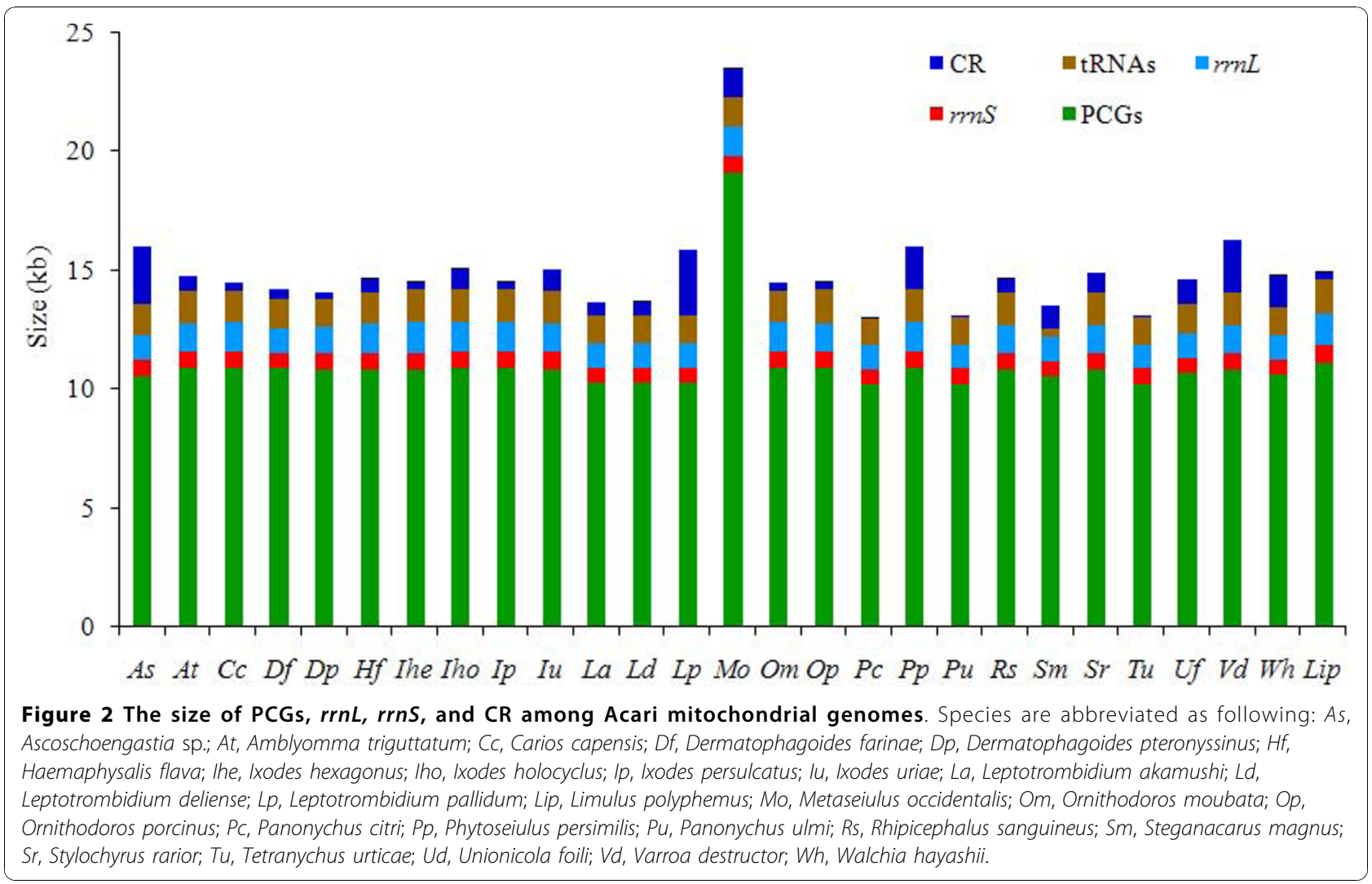

process. In the J-strand of $P$. citri mitochondrial genome, a short T-stretch ( $4 \mathrm{bp}$ ) has been found six nucleotides away from $\operatorname{cox} 1$, while a slightly longer T-stretch (6 bp) has been recognized in the $\mathrm{N}$-strand 17 nucleotides away from nad3 (Figure 3). Similar T-stretch (4 bp) is also found in the J-strand of P. ulmi $\mathrm{A}+\mathrm{T}$-rich region, but no $\mathrm{T}$-stretch can be found in the $\mathrm{N}$-strand of $P$. ulmi and on both strand of T. urticae (Figure 3). It has been shown that the $\mathrm{T}$-stretches vary in length, e.g., 4-10 nucleotides in the collembolan species, and $>10$ bp in holometabola $[28,29]$. While the minimum length of $\mathrm{T}$-stretch is not known, long $\mathrm{T}$ stretches ( $>10 \mathrm{bp}$ ) seem to be indispensable for the replication initiation of mtDNA [28]. Therefore, other sequences instead of the T-stretches may provide essential signals for the replication initiation of mtDNA in the species that do not possess the long $\mathrm{T}$-stretches, e.g., Locusta migratoria [28]. However, the A + T-rich regions are highly variable among $P$. citri, $P$. ulmi and T. urticae ( $75.0 \%$ sequence identity), and only several short conserved sequences can be recognized (Figure 3). On the other hand, the stem-loop secondary structure in the $\mathrm{A}+\mathrm{T}$-rich region may also be involved in the initiation of the replication of animal mtDNA [30]. The $\mathrm{A}+\mathrm{T}$-rich region of the three spider mites can be folded into stable stem-loop secondary structures
(Figure 3): two stem-loop structures are present in both $P$. citri and P. ulmi, whereas only one is found in $T$. urticae. It has been previously suggested that the sequence flanking the stem-loop structure is highly conserved among arthropods: a TATA motif in the 5'-flanking sequence and a GA(A)T motif in the 3'-flanking sequence [30]. Both motifs are presumed to have a functional significance in the replication and transcription of the mtDNA [30-32], but are not present in the A + T-rich regions of $P$. citri, P. ulmi, and T. urticae (Figure 3).

The gene order of the $P$. citri mitochondrial genome is identical to those of $P$. ulmi and T. urticae (the $\operatorname{trnK}$ of $P$. ulmi was misannotated on the opposite strand compared to P. citri, see below), but differs markedly from those of all other known Acari and chelicerates (Figure 1, Figure 4, Additional file 3, also see [14] and [33] for overviews of gene arrangement within Chelicerata). Compared to Limulus polyphemus, which is considered the representative ground pattern for arthropod mitochondrial genomes $[34,35]$, a series of gene rearrangements have occurred in the evolutionary history of $P$. citri; only nine of the 38 gene boundaries in $L$. polyphemus are conserved in P. citri. The most striking features are the inversions of two segments, which change the relative position and transcriptional orientation of six PCGs (cox3, atp6, atp8, cox2, nad4, and nad5) and 


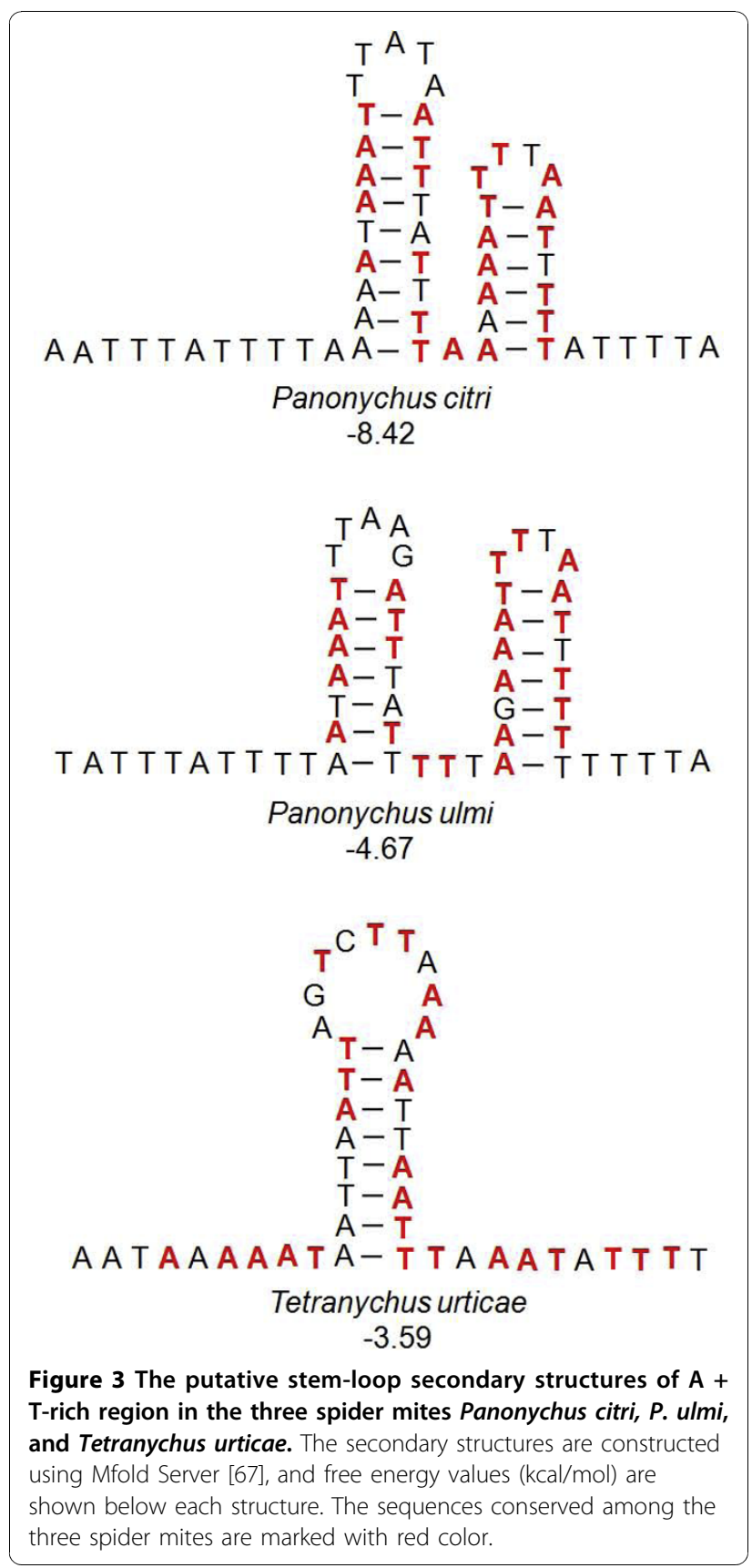

two tRNA genes $(\operatorname{trn} K$ and $\operatorname{trn} H)$; $\operatorname{trn} D$ may invert before or after the rearrangement of the fragment cox3cox 2 . All 22 tRNA genes and two rRNA genes are also severely rearranged, translocated and/or inverted, but do not show any particular patterns.

So far, the complete mitochondrial genomes of 26 species belonging to Acari have been sequenced and they exhibit great variation of gene order (Additional file 3). Among them, 7 of the 14 species belonging to the superorder of Parasitiformes (e.g. Ixodes spp.) share the same gene order as the ancestral chelicerates, while all of the 12 species belonging to the superorder of Acariformes are highly rearranged [14,33], suggesting that these gene arrangements within Acari are independently derived [33]. The rearrangement events (translocations and/or inversion) from other Acari (compared to L. polyphemus) do not seem to be more parsimonious to produce the gene arrangement of $P$. citri (Additional File 3). It is clear that the unique mitochondrial genome arrangement present in P. citri, P. ulmi, and T. urticae likely occurred after Tetranychidae diverged from other Acari, or after Acariformes split from Parasitiformes and Opilioacariformes, because this feature is not shared with any other Acari. Rearrangements of the mitochondrial genome should be relatively rare events at the evolutionary scale, and, therefore, provide a powerful tool to delimit deep divergences among some metazoan lineages [36]. However, the mitochondrial gene rearrangement phenomenon seems to occur frequently and independently in Acari mitochondrial genomes [8,33], possibly restricting the phylogenetic applications in recovering the evolutionary relationships between superorders within the Acari. On the other hand, gene order appears to be linked to taxonomic relatedness at the lower rank (i.e. genus, family). For example, the relationship between prostriate ticks and metastriate ticks can be distinguished by gene arrangements [31,37].

\section{Base composition and codon usage}

As is the case in other Acari mitochondrial genome sequences, the nucleotide composition of the $P$. citri mtDNA is also biased toward $\mathrm{A}$ and $\mathrm{T}$ (J-strand: $\mathrm{A}=$ $39.62 \%, \mathrm{~T}=45.66 \%, \mathrm{G}=7.58 \%, \mathrm{C}=7.14 \%$; Additional file 1). A comparative analysis of $\mathrm{A}+\mathrm{T} \%$ vs $\mathrm{AT}$-skew and $\mathrm{G}+\mathrm{C} \%$ vs $\mathrm{GC}$-skew across all available complete mitochondrial genomes of Acari and L. polyphemus is shown in Figure 5. The overall A $+\mathrm{T}$ content (85.28\%) of $P$. citri is similar to those of P. ulmi (85.60\%) and T. urticae $(84.27 \%)$, but much higher than the average $\mathrm{A}+\mathrm{T}$ content of Acari mitochondrial genomes (75.34 \pm $4.78 \%$ ) as well as that of L. polyphemus (67.57\%).

Metazoan mitochondrial genomes usually present a clear strand bias in nucleotide composition [38,39]. In detail, the J-strand is biased in favour of adenine and cytosine, while the $\mathrm{N}$-strand consequently contains more thymine and guanine. The strand bias can be measured as AT- and GC-skews [40]. The average AT-skew of Acari mitochondrial genome is $0.000 \pm 0.101$, ranging from - 0.253 in Dermatophagoides farinae to 0.264 in Walchia hayashii, whereas the P. citri mitochondrial genome exhibits a slight AT-skew (0.071) (Figure 5). The marked AT-skew values are shared by the mitochondrial genomes of D. farinae (-0.253), D. pteronyssinus (-0.199), Unionicola foili (0.201), and W. hayashii $(0.264)$. 


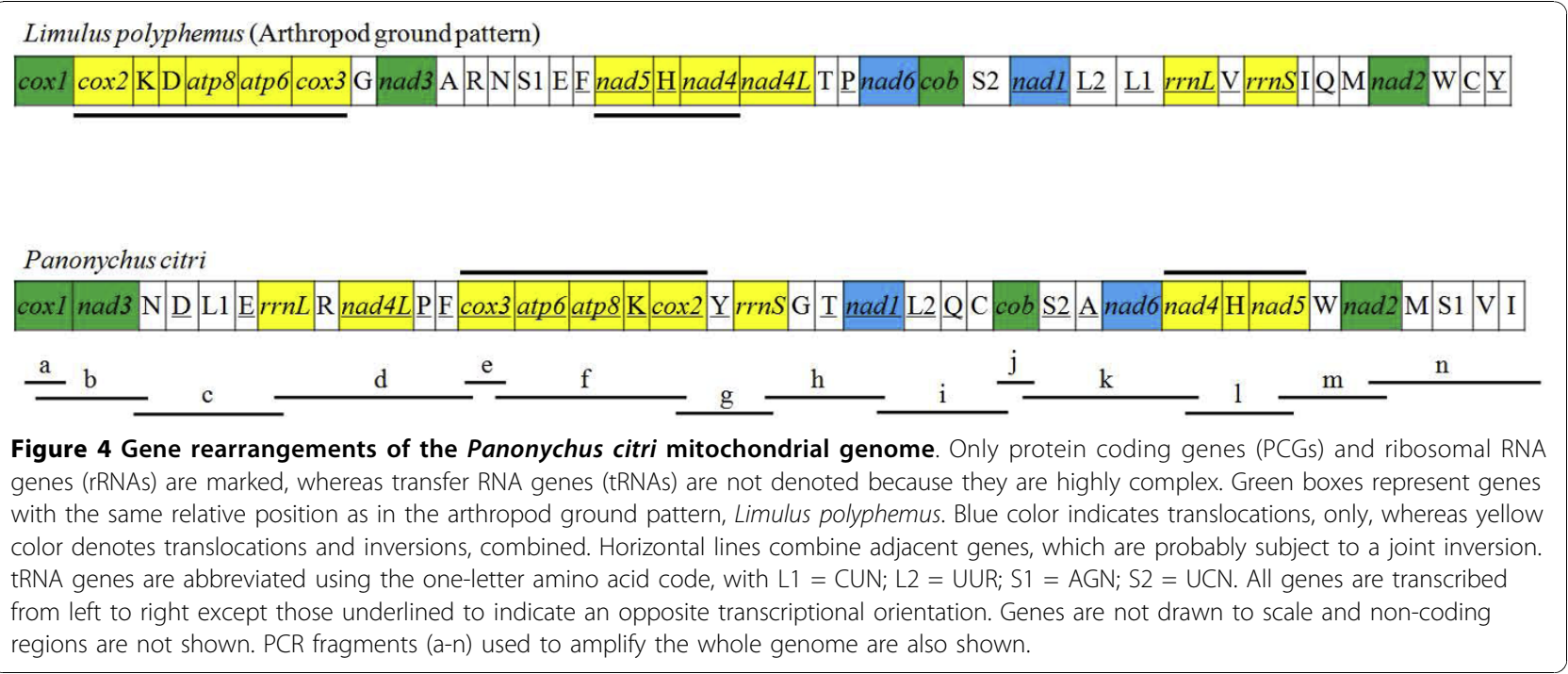

The average GC-skew of Acari mitochondrial genome is $-0.126 \pm 0.195$ and most of GC-skew values are negative, similar to those typically found in most metazoan mitochondrial genomes. However, as has been reported for other arthropods $[38,39,41-43]$, six mite species in four genera are characterized by a reversal of GC-skew: Dermatophagoides [14,15], Phytoseiulus [44], Varroa [45], and Panonychus (Figure 5). This reversal of the strand bias could be the result of inversion of the control region [38], which contains all initiation sites for replication and transcription of the mtDNA [46]. Therefore, an inversion of the control region is expected to produce a global reversal of asymmetric mutational constraints in the mtDNA, with time resulting in a complete reversal of strand compositional bias [38]. In the $P$. citri mtDNA most genes encoded on the J-strand show a positive GC-skew at the fourfold degenerate third codon position which is inverted to the common pattern and probably indicates a reversal of the control region (Additional file 1). Furthermore, this reverse strand bias may occur after the genus Panonychus split from the family Tetranychidae, because $T$. urticae, belonging to the same-family (Tetranychidae) with P. citri and P. ulmi, shows a usual GC-skew (negative), as found in most of Acari.

The analyses of the base composition at each codon position of the concatenated 13 PCGs of P. citri show that the third codon positions (92.9\%) have an $\mathrm{A}+\mathrm{T}$ content higher than that of the first (82.8\%) and second (79.4\%) codon positions, as has also been found in other sequenced Acari (Additional file 4). The relative synonymous codon frequencies (RSCU) reveal that codons harbouring $\mathrm{A}$ or $\mathrm{T}$ in the third position are always overused as compared to other synonymous codons in the P. citri mitochondrial genome (Table 1), as found in other sequenced Acari (Additional file 5) and other chelicerates [21,47]. Among 62 amino-acid encoding codons of invertebrate mitochondrial code [9], the P. citri mitochondrial genome uses 57 codons and never utilizes the five $\mathrm{G}+\mathrm{C}$ rich codons. Furthermore, the four AT-rich codons TTT-Phe (15.3), TTA-Leu (11.4), ATT-Ile (10.6), and ATA-Met (10.8) are the most frequently used codons in the P. citri PCGs, (Table 1). Comparative analyses among other sequenced Acari also reveal a similar pattern with the exceptions of $D$. farinae and S. magnus, and the values range from $26.40 \%$ in Leptotrombidium akamushi to $48.83 \%$ in P. ulmi (Additional file 5). This noted difference in the four most frequently used codons between Acari seems to be directly linked to the overall $\mathrm{A}+\mathrm{T}$ content (Additional file 6), as reported in other chelicerates and insects $[47,48]$.

\section{Protein-coding genes}

The total length of all the 13 PCGs is $10,196 \mathrm{bp}$, and accounts for $77.97 \%$ of the entire length of $P$. citri mitochondrial genome (Additional file 1). The overall $\mathrm{A}+\mathrm{T}$ content of PCGs is $73.91 \%$, ranging from $78.45 \%$ (cox 1 ) to $92.06 \%$ (nad6). All the PCGs start with ATN codons, which is typical for metazoan mitochondria [49]: one (cox1) with ATC, three (nad3, nad4L, and nad1) with ATA, four (cox2, cox3, atp6, and nad4) with ATG, and the other five with ATT (Additional file 1). Eight PCGs terminate with the conventional stop codons TAA (cox1, nad3, nad4L, atp6, cox2, nad2, and nad4) or TAG $(c o b)$, whereas the remaining five have incomplete stop codons $\mathrm{T}$. The presence of an incomplete stop codon is common in metazoan mitochondrial genomes [49] and these truncated stop codons are presumed to be completed via post-transcriptional polyadenylation [50]. A comparison of codon numbers across the 

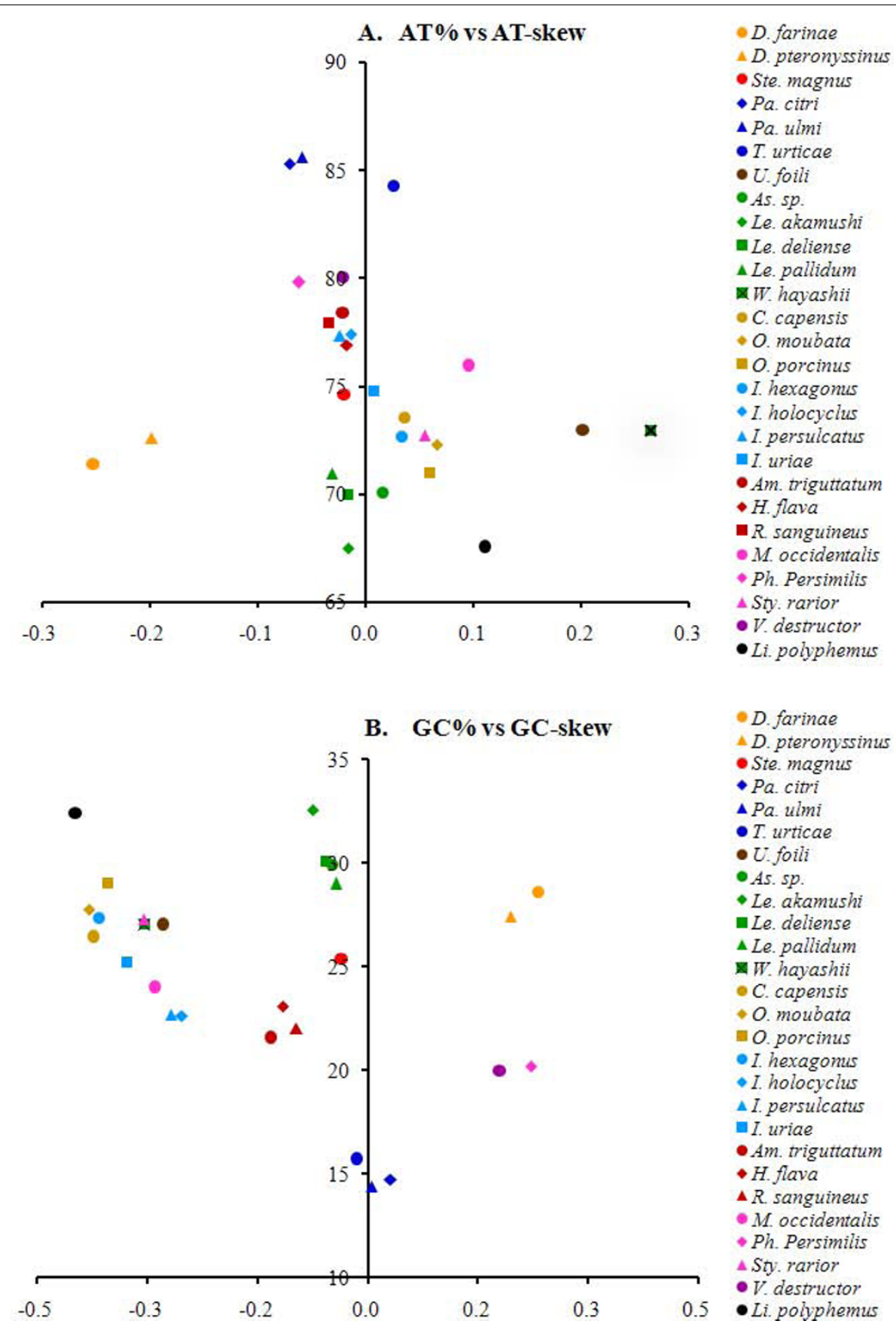

Figure 5 AT\% vs AT-skew and GC\% vs GC-skew in the 26 Acari mitochondrial genomes. Measured in bp percentage ( $Y$-axis) and level of nucleotide skew (X-axis), following [48]. Values are calculated on J-strands for full length mitochondrial genomes. A, A + T\% vs AT-skew; B, G + C $\%$ vs GC-skew. Genome sequence from Limulus polyphemus is also shown for a comparative analysis. See Additional file 11 for the GenBank accession numbers and full names of species.

sequenced Acari mitochondrial genomes shows that all PCGs are highly variable in length, covering a range from $3,389 \mathrm{bp}$ in P. citri to 6,328 bp in M. occidentalis (Figure 2). Notably, the M. occidentalis mitochondrial genome has the largest number of codons within chelicerates due to the duplication of many PCGs, even though nad3 and nad6 are lost [11]. However, a recent study has found that the M. occidentalis mtDNA is smaller than originally suggested, and nad3 is not lacking but is in fact located between nad4L and $r r n S$ [44]. P. citri, P. ulmi, and T. urticae have a reduction in mean content of 19.8, 19.8, and 19.0 codons per PCG, 
Table 1 Codon usage for the 13 mitochondrial proteins of Panonychus citri

\begin{tabular}{|c|c|c|c|c|c|c|c|c|c|}
\hline$\overline{A A}$ & Codon & $\mathrm{n}$ & $\%$ & RSCU & $A A$ & Codon & $n$ & $\%$ & $\mathrm{RSCU}$ \\
\hline \multirow[t]{2}{*}{ Stop } & UAA & 0 & 0 & 0 & Asn (N) & AAC & 24 & 0.71 & 0.17 \\
\hline & UAG & 0 & 0 & 0 & & AAU & 262 & 7.76 & 1.83 \\
\hline \multirow[t]{4}{*}{ Ala (A) } & GCU & 39 & 1.16 & 3.06 & Pro (P) & $\mathrm{CCU}$ & 53 & 1.57 & 3.21 \\
\hline & GCG & 1 & 0.03 & 0.08 & & CCG & 0 & 0 & 0 \\
\hline & GCC & 1 & 0.03 & 0.08 & & CCC & 4 & 0.12 & 0.24 \\
\hline & GCA & 10 & 0.30 & 0.78 & & CCA & 9 & 0.27 & 0.55 \\
\hline \multirow[t]{2}{*}{ Cys (C) } & UGU & 16 & 0.47 & 1.68 & $\mathrm{Gln}(\mathrm{Q})$ & CAG & 2 & 0.06 & 0.14 \\
\hline & UGC & 3 & 0.09 & 0.32 & & CAA & 26 & 0.77 & 1.86 \\
\hline \multirow{2}{*}{$\begin{array}{l}\text { Asp } \\
\text { (D) }\end{array}$} & GAU & 38 & 1.13 & 1.73 & $\operatorname{Arg}(\mathrm{R})$ & CGA & 16 & 0.47 & 2.29 \\
\hline & GAC & 6 & 0.18 & 0.27 & & CGC & 0 & 0 & 0 \\
\hline \multirow[t]{2}{*}{ Glu (E) } & GAG & 10 & 0.30 & 0.31 & & CGG & 0 & 0 & 0 \\
\hline & GAA & 55 & 1.63 & 1.69 & & CGU & 12 & 0.36 & 1.71 \\
\hline \multirow[t]{2}{*}{$\begin{array}{l}\text { Phe } \\
\text { (F) }\end{array}$} & UUU & 516 & 15.28 & 1.90 & $\begin{array}{c}\text { Ser1 } \\
(S)\end{array}$ & $\mathrm{GCC}$ & 8 & 0.24 & 0.22 \\
\hline & UUC & 28 & 0.83 & 0.10 & & AGA & 65 & 1.93 & 1.75 \\
\hline \multirow[t]{4}{*}{ Gly (G) } & GGU & 30 & 0.89 & 1.29 & & AGG & 0 & 0 & 0 \\
\hline & GGG & 14 & 0.41 & 0.60 & & AGU & 39 & 1.16 & 1.05 \\
\hline & GGC & 2 & 0.06 & 0.09 & $\begin{array}{c}\text { Ser2 } \\
(\mathrm{S})\end{array}$ & UCA & 48 & 1.42 & 1.29 \\
\hline & GGA & 47 & 1.39 & 2.02 & & UCC & 8 & 0.24 & 0.22 \\
\hline \multirow[t]{2}{*}{ His $(H)$} & CAC & 4 & 0.12 & 0.17 & & JCG & 1 & 0.03 & 0.03 \\
\hline & CAU & 42 & 1.24 & 1.83 & & UCU & 129 & 3.82 & 3.46 \\
\hline \multirow[t]{2}{*}{ lle (I) } & AUU & 359 & 10.63 & 1.87 & Thr $(T)$ & $A C A$ & 35 & 1.04 & 1.46 \\
\hline & $A \cup C$ & 26 & 0.77 & 0.14 & & ACC & 2 & 0.06 & 0.08 \\
\hline \multirow[t]{2}{*}{ Lys (K) } & AAA & 150 & 4.44 & 1.86 & & ACG & 2 & 0.06 & 0.08 \\
\hline & AAG & 11 & 0.33 & 0.14 & & $A C U$ & 57 & 1.69 & 2.38 \\
\hline \multirow{4}{*}{$\begin{array}{l}\text { Leu1 } \\
\text { (L1) }\end{array}$} & CUA & 22 & 0.65 & 1.42 & Val (V) & GUC & 1 & 0.03 & 0.04 \\
\hline & CUC & 0 & 0 & 0 & & GUG & 2 & 0.06 & 0.08 \\
\hline & CUG & 3 & 0.09 & 0.19 & & GUU & 51 & 1.51 & 2.13 \\
\hline & CUU & 37 & 1.10 & 2.39 & & GUA & 42 & 1.24 & 1.75 \\
\hline \multirow{2}{*}{$\begin{array}{l}\text { Leu2 } \\
\text { (L2) }\end{array}$} & UUA & 385 & 11.40 & 1.86 & $\operatorname{Trp}(\mathrm{W})$ & UGA & 44 & 1.30 & 1.91 \\
\hline & UUG & 28 & 0.83 & 0.14 & & UGG & 2 & 0.06 & 0.09 \\
\hline \multirow{2}{*}{$\begin{array}{l}\text { Met } \\
\text { (M) }\end{array}$} & AUG & 29 & 0.86 & 0.15 & $\operatorname{Tyr}(Y)$ & UAC & 17 & 0.50 & 0.22 \\
\hline & $A \cup A$ & 363 & 10.75 & 1.85 & & UAU & 140 & 4.15 & 1.78 \\
\hline
\end{tabular}

A total of 3,376 codons for $P$. citri are analyzed, excluding the start and stop codons. AA, amino acid; RSCU, Relative synonymous codon usage; $\mathrm{n}=$ frequency of each codon. $\%=n / 3376$.

respectively, making them the three smallest mitochondrial genomes within Acari.

The 13 PCGs of P. citri were combined with those of other Acari to investigate the evolutionary patterns among PCGs in Acari. The nucleotide substitution rates per site greatly vary among genes (Figure 6). In this respect, $n a d 1$ shows the highest value $(3.69 \pm 0.24)$, followed by nad6, while cox 1 appears to be the lowest. The number of synonymous substitutions per synonymous site (Ks) of cox3 is the highest, but its number of nonsynonymous substitutions per nonsynonymous site $(K a)$ is much lower, while this value for nad1 is the highest. Therefore, at the nucleotide and amino acid levels, cox 1 is the slowest evolving protein, making it a useful marker for investigating phylogenetic relationships at higher taxonomic levels. However, a DNA barcoding approach based on $\operatorname{cox} 1$ sequence diversity has been utilized for identification of closely related species [51]. By contrast, due to the highest divergence, nad1 can be used as an effective molecular marker to analyze intraspecific relationships and reveal relationships between populations within the same Acari species. The $K s$ of each PCG has a relatively high value compared to $K a$, which may indicate that these genes are evolving under purifying selection $[16,52]$. Notably, nad1 accumulates amino acid substitutions twice as fast as the Acari mitochondrial average, possibly implying positive selection acting at nad1 or due to relax selection. Furthermore, a negative correlation has been found between the $K a / K s$ and the GC content of each PCG $(\mathrm{R}=-0.676, P=0.011)$, indicating that the variation of GC content probably causes the different evolutionary patterns among genes [23].

\section{Transfer and ribosomal RNA genes}

The two genes encoding the large and small rRNA subunits ( $r r n L$ and $r r n S$ ) are located between $\operatorname{trnE}$ and $\operatorname{trnR}$, and between $\operatorname{trn} Y$ and $\operatorname{trn} G$ (Figure 1, Additional file 1). Both genes are encoded on the J-strand, as in P. ulmi, T. urticae [3], M. occidentalis [11], and Phytoseiulus persimilis [44], and in the two genera Dermatophagoides $[14,15]$ and Leptotrombidium (but L. pallidum has a duplicated $r r n L$ gene on the N-strand) $[10,13]$. In contrast, in the mitochondrial genomes of other Acari and most species of chelicerates and arthropods, both rRNA genes are encoded on the N-strand $[12,31,33,34,43,47,53,54]$. We annotate the 5'- and 3'ends of two rRNA genes as the first nucleotide downstream and upstream of corresponding tRNA genes, respectively, and the size of the $r r n L$ and $r r n S$ of $P$. citri are $989 \mathrm{bp}$ and $648 \mathrm{bp}$ long, respectively (Additional file $1)$. The $\mathrm{A}+\mathrm{T}$ contents of $r r n L$ and $r r n S(86.66 \%$ and $87.54 \%$, respectively) are similar to those of $P$. ulmi (86.76\% and $88.01 \%$, respectively) and T. urticae (85.27\% and $85.91 \%$, respectively), but much higher than the average value of Acari $(78.58 \pm 4.57 \%$ and $77.17 \pm$ $5.08 \%$, respectively). The boundaries of some tRNA genes are incorrectly delimited in P. ulmi, T. urticae and another strain of $P$. citri (see below). This aspect affects the boundaries of $r r n L$ and $r r n S$ in these taxa. Thus we re-annotate also these genes (Additional file 2). The size of $r r n L$ and $r r n S$ of $P$. citri is similar to those of another P. citri strain (992 bp and 650 bp), P. ulmi (983 bp and $659 \mathrm{bp}$ ) and T. urticae (992 bp and $645 \mathrm{bp}$ ). The size of 


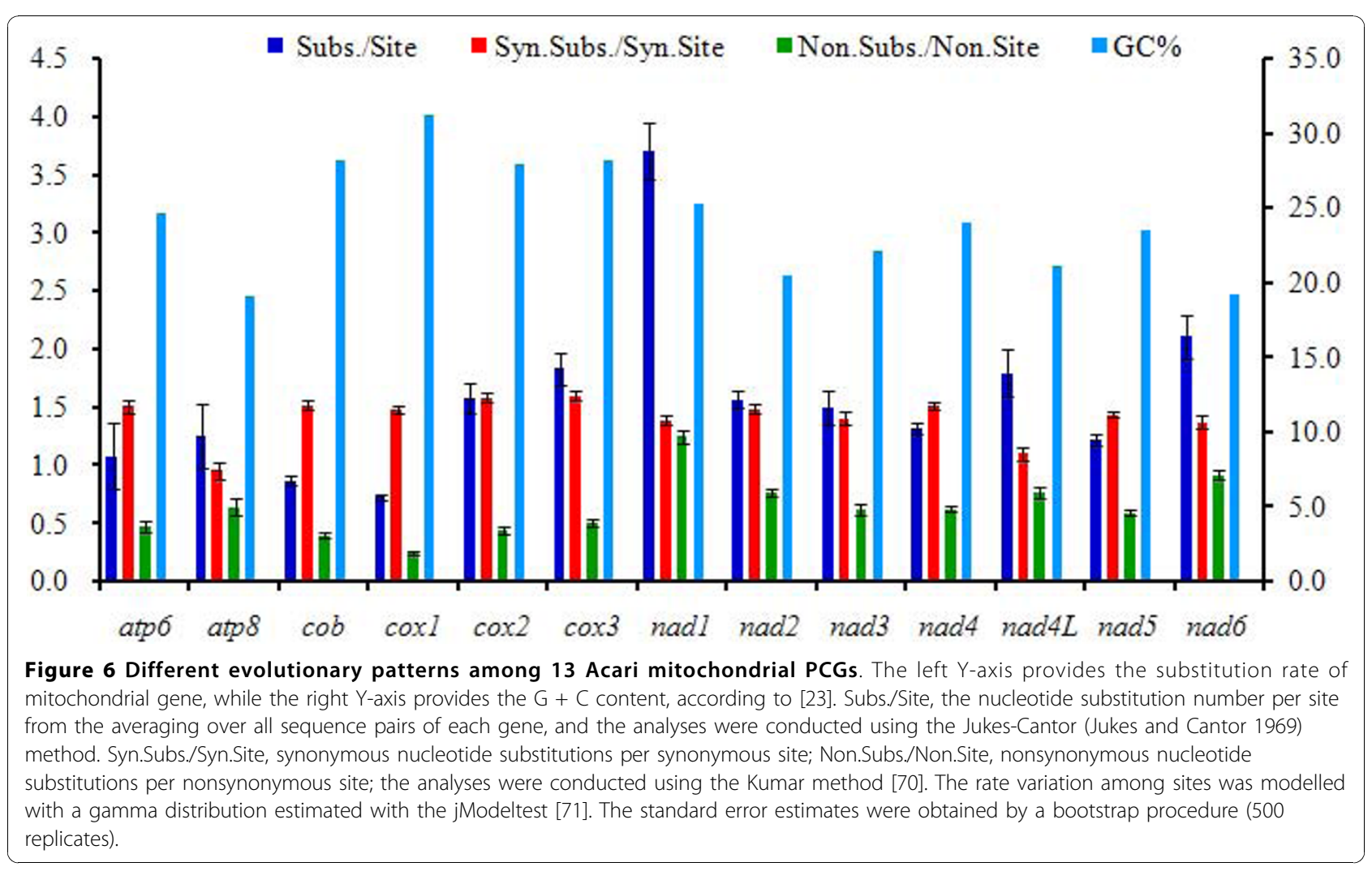

rrnL of $P$. citri is the second shortest among all sequenced Acari mitochondrial genomes, whereas the size of $r r n S$ is slightly larger than those of other Acariform mites $(637.83 \pm 27.70 \mathrm{bp})$, but are much shorter than those found in the Parasitiformes $(702.57 \pm 21.52$ bp) (Figure 2).

The secondary structures of the two rRNA genes inferred for $P$. citri have similar stem-loop structures as those published for L. pallidum [13] and D. pteronyssinus [14] (Figure 7, Figure 8). All the helices of the $r r n L$ found in L. pallidum are present in P. citri; however, three helices (C1, E2 and E19) found in D. pteronyssinus are not present in $P$. citri. The lack of helix $C 1$ is largely due to the size reduction of the $P$. citri $r r n L$ compared to the $D$. pteronyssinus $r r n L$, and the deleted nucleotides are mainly located at 5'-end. The helix H3 is similar in size to those of $L$. pallidum and D. pteronyssinus, but appears to be lost in P. ulmi and T. urticae, though the length of the three spider mite species is similar. Compared to the 5 '-end, the 3 '-end of $r r n L$ structure is more conserved among P. citri, P. ulmi, and T. urticae (Figure 7), especially for the helices G16-G20. In addition, the loop region of helix $\mathrm{H} 2$ is highly conserved not only in Tetranychidae, but also in the other two mite genera Leptotrombidium [10,13] and Dermatophagoides [14,15]. Like in L. pallidum and D. pteronyssinus, one compound helix replaces three helices (24-25-26) of the Drosophila yakuba $r r n S$ [13]. In the middle of $r r n S$, two helices (39 and 42) are present in P. citri, which is more similar to that of S. magnus [12], but only a compound helix (3940-41-42) is present in L. pallidum and D. pteronyssinus. In addition, the helix 1 not present in L. pallidum is found in the rrnS of $P$. citri; this helix is also found in D. pteronyssinus. The most conserved sequences of $r r n S$ among Tetranychidae are found in the helices 19, 21, 32, 33, 49, and 50 (Figure 8).

Out of 22 tRNA genes usually present in metazoan mitochondrial genomes, only 13 tRNA genes can be detected in the $P$. citri mitochondrial genome by tRNAscan-SE [55] and/or ARWEN [56]. The remaining nine tRNA genes $(\operatorname{trn} N, \operatorname{trn} D, \operatorname{trn} P, \operatorname{trn} Y, \operatorname{trn} S 2, \operatorname{trn} A, \operatorname{trn} S 1$, $\operatorname{trn} V, \operatorname{trn} I)$ were identified by manually aligning unassigned sequences to known tRNA genes from T. urticae and P. ulmi, as suggested by Masta and Boore [43]. All 22 tRNA sequences were aligned with those of $P$. ulmi and T. urticae, and show high similarity among Tetranychidae, especially for the anticodon stem (Additional file 7). However, only eight tRNA genes $(\operatorname{trn} F, \operatorname{trn} Y, \operatorname{trn} T$, trnL2, trnC, trnH, trn W, and trnM) of both P. ulmi and T. urticae are correctly annotated on GenBank. Among the remaining tRNA genes, the boundaries of ten tRNA genes of another $P$. citri strain (trnR, trnP, trnG, trnT, $\operatorname{trn} Q, \operatorname{trn} C, \operatorname{trn} A, \operatorname{trn} S 1, \operatorname{trn} V$, and $\operatorname{trn} I)$ and T. urticae $(\operatorname{trn} N, \operatorname{trn} D, \operatorname{trn} E, \operatorname{trn} P, \operatorname{trn} G, \operatorname{trn} Q, \operatorname{trnS} 2, \operatorname{trn} A, \operatorname{trn} V$, 


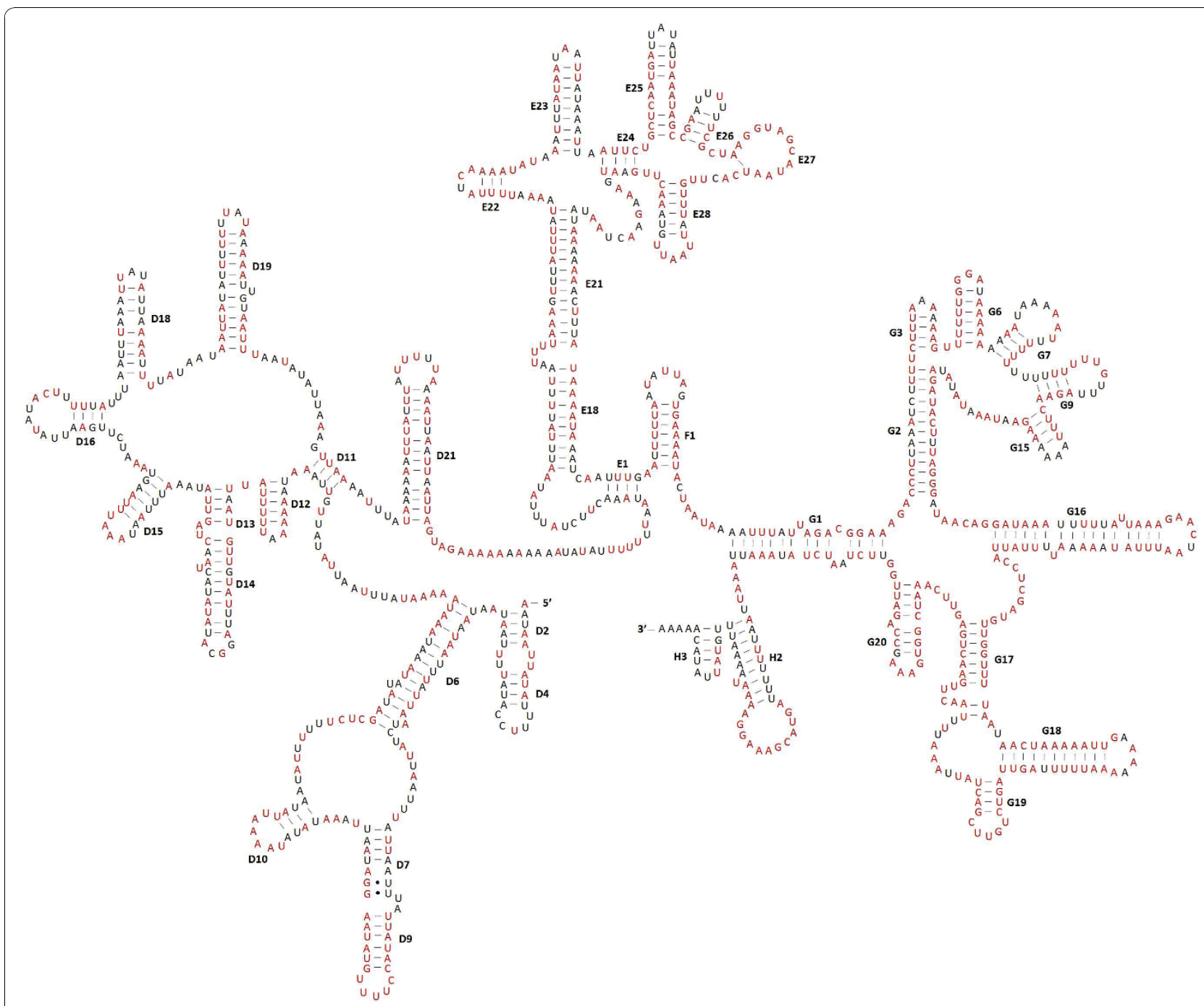

Figure 7 Inferred secondary structure for the $r r n L$ in Panonychus citri. The helix numbering is after [72]. The nucleotides showing 100\% identity among P. citri, P. ulmi, and Tetranychus urticae are marker with red color. Inferred Watson-Crick bonds are illustrated by lines, whereas GU bonds are illustrated by dots.

and $\operatorname{trnI})$, and 11 tRNA genes of P. ulmi $(\operatorname{trnN}, \operatorname{trnL1}$, $\operatorname{trnR}, \operatorname{trn} P, \operatorname{trn} K, \operatorname{trn} Q, \operatorname{trn} S 2, \operatorname{trn} A, \operatorname{trnS1}, \operatorname{trn} V$, and $\operatorname{trn} I)$ were incorrect on GenBank (Additional file 2), because most of them appear to lack the sequences to form the canonical amino acid acceptor stem (seven nucleotides) or at least one D- or T-arm (Additional file 8). The $\operatorname{trnK}$ of $P$. ulmi is misannotated on the J-strand, but in this location an unpaired anticodon stem is found. In fact, the majority of the nucleotides of trnK among Tetranychidae are highly conserved (Additional file 7), and only when $\operatorname{trnK}$ of $P$. ulmi is on the N-strand, as in $P$. citri and T. urticae, can canonical secondary structure of tRNA genes be found (Additional file 8). Therefore, we re-annotate these tRNA genes to incorporate the conserved structural features of tRNA genes (e.g., the possession of seven nucleotides in the amino acid acceptor stem, and at least one T- or D-arm) (Additional file 2), and present their secondary structures in Additional file 8.

Eleven tRNA genes overlap with adjacent genes in a total of $55 \mathrm{bp}$, as in another $P$. citri strain, whereas ten and nine gene overlaps are present in $P$. ulmi and $T$. urticae, respectively (Additional file 2). The most truncated tRNA genes are $\operatorname{trn} Q, \operatorname{trn} A$, and $\operatorname{trn} I$ in P. citri, whose sequences overlap the $\operatorname{trn} L 2$, nad6 and $\operatorname{trn} V$ on the same or opposite strand for 13,10, and 14 nucleotides, respectively (Additional file 1 ). The similar situations are found in P. ulmi and T. urticae (Additional file 2 ). The similar amount of gene overlap on the same strand has been reported for the spider Habronattus oregonensis [43] and the house dust mite D. pteronyssinus [14]. Furthermore, if the three tRNA genes $(\operatorname{trn} Q$, 


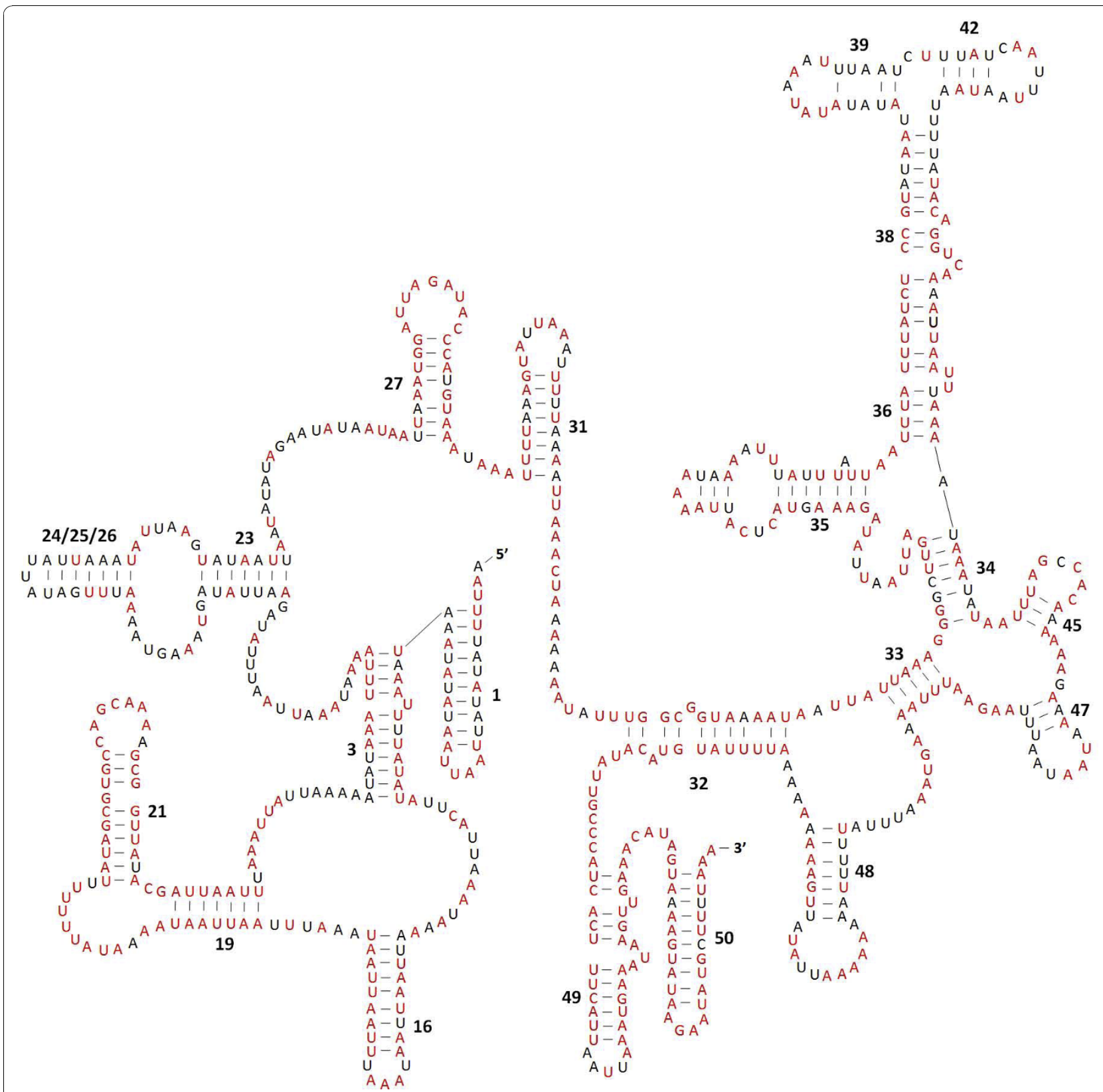

Figure 8 Inferred secondary structure for the rrnS in Panonychus citri. The helix numbering is after [73]. The nucleotides showing 100\% identity among P. citri, P. ulmi and Tetranychus urticae are marker with red color. Inferred Watson-Crick bonds are illustrated by lines, whereas GU bonds are illustrated by dots.

$\operatorname{trn} A$, and $\operatorname{trn} I$ ) do not overlap adjacent genes, they lack the sequences to form either the usual amino acid acceptor stem or at least one D- or T-arm. In addition, the nucleotides present in the anticodon arm of the three tRNA genes are highly conserved among Tetranychidae (Additional file 7). Other gene overlaps found in tRNA genes of Tetranychidae are not more than five nucleotides (Additional file 2). The average size (54.1 \pm $4.1 \mathrm{bp}$ ) of tRNA genes found in P. citri is similar to those of P. ulmi $(55.1 \pm 4.5)$ and T. urticae $(54.1 \pm 3.6$ $\mathrm{bp})$, reducing the potential of tRNA genes to form a typical metazoan cloverleaf structure (Figure 9). In fact, the average size of tRNA genes of Acariformes (mean = $54.8 \pm 1.0 \mathrm{bp}$ ) is considerably shorter with respect to those of all species of Parasitiformes (mean $=62.0 \pm 1.3$ bp) as well as $L$. polyphemus (mean $=66.3 \pm 2.5 \mathrm{bp}$, Additional file 9), indicating that atypical tRNA genes may be a common phenomenon in Acariformes.

Out of 22 tRNA genes, only three tRNA genes ( $\operatorname{trn} N$, $\operatorname{trnL2}$, and $\operatorname{trnK}$ ) can potentially fold into a typical 

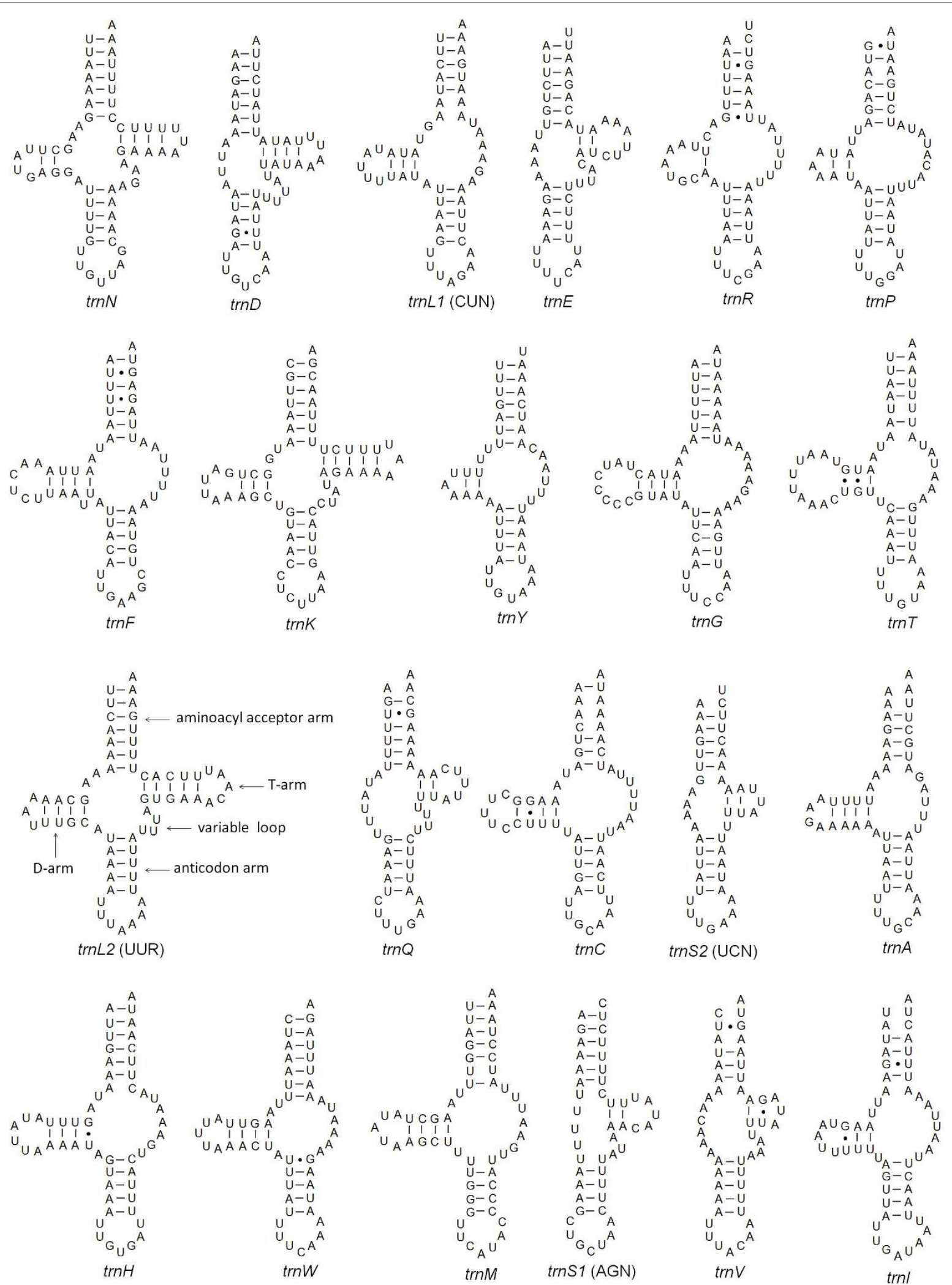

Figure 9 Putative secondary structures of the 22 tRNA genes identified in the mitochondrial genome of Panonychus citri. tRNA genes are shown in the order of occurrence in the mitochondrial genome starting from cox1. Bars indicate Watson-Crick base pairings, and dots between $\mathrm{G}$ and $\mathrm{U}$ pairs mark canonical base pairings appearing in RNA. 
cloverleaf structure, whereas all the remaining 19 tRNA genes appear to lack the sequence to code the $\mathrm{D}$ - or $\mathrm{T}$ arm (Figure 9), as found in P. ulmi and T. urticae (Additional file 8). In at least 13 tRNA genes, the T-arm has been substituted by a loop of variable size (TVreplacement), whereas another six tRNA genes (trnD, $\operatorname{trn} E$, $\operatorname{trn} Q, \operatorname{trn} S 1, \operatorname{trn} S 2$, and $\operatorname{trn} V)$ show a Dreplacement loop instead of the D-arm (Figure 9). With the exception of $\operatorname{trnP}$, which seems to be lost the D-arm in P. ulmi, all tRNA genes have similar secondary structures among Tetranychidae (Figure 9, Additional file 8). The loss of the D-arm in trnS1 (AGN) has been considered a typical feature of metazoan mitochondrial genomes [49]. The absence of the T-arm seems to be a common feature for the tRNA genes of chelicerates from the orders of the Araneae, Scorpiones, Thelyphonida, and Acariform Acari [10,13-15,43,57], whereas other orders (Amblypygi, Opiliones, Solifugae, and Parasitiform Acari) possess typical metazoan cloverleaf tRNAs [57]. On the other hand, the loss of the D-arm of tRNA genes is an uncommon circumstance but has been reported for a few of mitochondrial tRNA genes from chelicerates, including the scorpion Centruroides limpidus [58], the sea spiders Nymphon gracile [47] and Achelia bituberculata [21], and five mites belonging to two genera Leptotrombidium [10,13] and Dermatophagoides [15]. It has been shown that in the nematode Ascaris suum the tRNA genes that lack either the D- or $\mathrm{T}$-arm are functional [59], but functional tRNA genes that lack both the D- and T-arms have not been found before. However, tRNA genes that lack both T- and Darms have been reported for the sea spider $A$. bituberculata $(\operatorname{trn} A)[21]$ and the scorpion C. limpidus (trnQ and trnS1) [58]. In the American house dust mite D. farinae, some tRNA genes (e.g. $\operatorname{trn} A$ ) lacking the $\mathrm{D}$-arm have a small (2-3 bp) and thermodynamically unstable T-arm, suggesting that these tRNA genes may have lost both Dand $\mathrm{T}$-arms in reality [15]. In this study, we also found that some inferred T-arms (e.g., trnS2, trnV) or D-arms (e.g., $\operatorname{trn} Y, \operatorname{trnR}, \operatorname{trn} P$ ) were short (Figure 9). In particular, the inferred D-arm of $\operatorname{trn} Y$ in P. ulmi and T. urticae (only one bp) is shorter than in P. citri, whereas the Darm of trnP is lost in P. ulmi, casting doubt on their identity as D-arms. Therefore, further experiments are needed to investigate whether these truly tRNA genes lack both D- and T-arms and if so, whether they are functional.

Twenty of 22 tRNA genes have a five bp well-paired anticodon stem, and the remaining two tRNA genes (trnM and $\operatorname{trnS1}$ ) have a single mismatch within this stem. All tRNA genes, but trnI, have the seven canonical nucleotides in the anticodon loop, whereas trnI has eight nucleotides in this region, which is also found for trnI of $P$. ulmi and T. urticae (Additional file 8). These noncanonical anticodon loops are not common, but have also been reported for the house dust mite D. pteronyssinus (trnL2) [14], the scorpion Mesobuthus gibbosus (trnH and $\operatorname{trn} N$ ) [58], and the wild two-humped Camelus bactrianus ferus (trnS1) [60]. Only nine of the 22 tRNA genes have a completely matched seven bp aminoacyl acceptor stem (trnN, trnD, trnE, trnG, trnL2, trnK, trnF, $\operatorname{trn} W$, and $\operatorname{trn} Y$ ), while the remaining 13 tRNA genes have 1-3 bp mismatches in this stem. This type of a mispaired acceptor stem seems to be a common phenomenon for tRNA genes of chelicerates (e.g., Araneae $[42,43]$, Acari [14,15], Scorpiones [58]), and a posttranscriptional RNA editing mechanism has been proposed to maintain function of these tRNA genes [43,61].

\section{Conclusions}

We sequenced the complete mitochondrial genome of the spider mite, $P$. citri (Family Tetranychidae). This mitochondrial genome in size is similar to those of other spider mites, $P$. ulmi and T. urticae, and is the smallest among all sequenced Acari and other Chelicerate genomes. The gene order of the $P$. citri mtDNA is identical to those of $P$. ulmi and T. urticae, but markedly differs from those of other chelicerates by a large number of gene inversions and/or translocations, suggesting that rearrangements occurred after Tetranychidae diverged from other Acari. Comparative analyses among Acari mitochondrial genomes show that the genome size, gene order, gene content, codon usage, and base composition are strongly variable. The Acari mitochondrial nad1 exhibits a faster amino acid substitution rate than the average, and the $\mathrm{G}+\mathrm{C}$ content variation causes the different evolutionary patterns among genes of Acari mitochondrial genomes. Most tRNA genes present in P. citri are minimal and atypical, lacking the D- or T-arm, as found in P. ulmi and T. urticae. While extremely short and unusual tRNA genes seem to be common for Acariform mites, further experimental evidence is needed.

\section{Methods}

\section{Samples and DNA extraction}

Female adult of $P$. citri was collected on Trifoliate orange from Citrus Research Institute of Chinese Academy of Agricultural Sciences, Chongqing, China. Total DNA was extracted from about 800 females using a CTAB-based protocol [62] and stored at $-20^{\circ} \mathrm{C}$.

\section{PCR amplification and sequencing}

Fourteen pairs of PCR primers were employed to amplify overlapping segments of the entire mitochondrial genome of $P$. citri. Initially, cox 1 and $c o b$ genes were amplified using the primers COI-F/R [63,64] and CB3-F/CB4-R [65], respectively. Four perfectly matching primers, namely cox1-R1, cox1-F4, cob-R3 and cob-F3, 
were designed on the basis of the sequence information from $\operatorname{cox} 1$ and $c o b$. Other primers were designed based on the conserved nucleotide sequences in T. urticae [3] and P. ulmi (GenBank: NC_012571). A full of list of primers as well as PCR conditions are presented in Additional file 10. All PCR products were separated by electrophoresis on a $1 \%$ agarose gel, purified with DNA Gel Purification Kit (Watson, Shanghai), and cloned into the pGEM-T vector (Promega, USA). After heat-shock transformation of Escherichia coli (Trans $5 \alpha$, Beijing TransGen Biotech) cells, the positive recombinant clone with an insert was sequenced with M13 primers on both strands.

\section{Sequence assembly, annotation and analysis}

Sequence data were assembled using SeqMan software (DNAStar, Inc.). Protein coding genes (PCGs) were identified by ORF Finder implemented at the NCBI website with the invertebrate mitochondrial genetic codes and by comparison with the published Acari mitochondrial sequences with Clustal W 2.0 [66]. Two large non-protein-coding regions were candidates for the rRNA genes ( $r r n L$ and $r r n S$ ). The boundaries were determined based on alignments and secondary structures of rRNA sequences of other mite species. The tRNA genes were identified by their cloverleaf secondary structure using tRNAscan-SE 1.21 [55] and ARWEN [56]. For tRNAscan-SE the following parameters were changed: Search Mode = "EufindtRNA-Cove", Source = "Nematode Mito", Genetic Code = "Invertebrate Mito" and Cove score cutoff $=0.1$. ARWEN was run with default parameters. Other tRNA genes were identified by aligning to known tRNA genes from $P$. ulmi and $T$. urticae [43]. The secondary structure models for two rRNA genes of $P$. citri were constructed by comparison with the published rRNA secondary structures for $L$. pallidum [13], D. pteronyssinus [14], and S. magnus [12]. The secondary structure of $\mathrm{A}+\mathrm{T}$-rich region (putative control region) was constructed using Mfold Server [67]. The complete mitochondrial genome sequence of $P$. citri has been deposited in the GenBank database under the accession number HM189212. The base composition, codon usage, and nucleotide substitution were analyzed with Mega 4.0 [68] and DAMBE 5.0.59 [69]. Mitochondrial genome sequences from other Acari and the horseshoe crab L. polyphemus were obtained for comparative analyses (see Additional file 11 for GenBank accession numbers).

\section{Additional material}

Additional file 1: Summary of the mitochondrial genome of Panonychus citri.
Additional file 2: Comparisons of mitochondrial genome organizations of Panonychus citri, P. ulmi and Tetranychus urticae.

Additional file 3: Mitochondrial genome arrangements of 26 Acari. Only protein coding genes (PCGs) and ribosomal RNA genes (rRNAs) are given, whereas transfer RNA genes (tRNAs) are not depicted because they are highly complex. White boxes represent genes with the same relative position as in the arthropod ground pattern, Limulus polyphemus. Blue color indicates translocations, only, whereas yellow color denotes translocations and inversions, combined. All genes are transcribed from left to right except those underlined to indicate an opposite transcriptional orientation.

Additional file 4: Base composition at each codon position of the concatenated 13 PCGs in the Acari mitochondrial genomes. See Figure 2 for the full names of species.

Additional file 5: Amino acid usage of mitochondrial protein-coding genes from other Acari.

Additional file 6: The correlation between the four most frequently used codons and overall $A+T$ content in the Acari mitochondrial genomes.

Additional file 7: Alignment of the sequences of the 22 mitochondrial tRNA genes of Panonychus citri, $P$. ulmi and Tetranychus urticae. $\mathrm{PC}-\mathrm{Y}$ is Panonychus citri in this study; $\mathrm{PC}-\mathrm{L}$ is another P. citri strain (GenBank: NC_014347); Pu is P. Ulmi; Tu is Tetranychus urticae. The anticodon arms are indicated with underlines.

Additional file 8: The inferred secondary structures of tRNA genes of another Panonychus citri strain, P. ulmi, and Tetranychus urticae. The added nucleotides are indicated in red color, whereas the deleted nucleotides are underlined, compared to the original annotations of tRNA genes on GenBank. PC-L is another P. citri strain (GenBank: NC_014347).

Additional file 9: Average size of tRNA genes of 26 Acari mitochondrial genomes. The Acariformes are indicated by red color and the Parasitiformes by blue color. See Figure 2 for the full names of species.

Additional file 10: Primer sequences and PCR conditions used to amplify the mitochondrial genome of Panonychus citri.

Additional file 11: GenBank accession numbers of mitochondrial genomes for other Acari and the horseshoe crab Limulus polyphemus.

\section{Abbreviations}

PCGs: protein-coding genes; atp6 and atp8: genes for the ATPase subunits 6 and 8; cox1-cox3: genes for cytochrome C oxidase subunits I-III; cob: a gene for apocytochrome b; nad1-nad6 and nad4L: genes for NADH

dehydrogenase subunits 1-6 and 4L; rrnL: large (16S) rRNA subunit (gene); rrnS: small (12S) rRNA subunit (gene); $\operatorname{trn} X$ (where $X$ is replaced by one letter amino acid code of the corresponding amino acid), transfer RNA.

\section{Acknowledgements}

We are grateful to five anonymous referees for providing invaluable comments and suggestions. We thank Dr. Helen Hull-Sanders and Stephen Sanders for critical reading of the manuscript. We also thank Mr. Fei Lu and Chen-Xiao Hu for the technical assistance in genome sequencing. This study was supported in part by a Special Fund for Agro-scientific Research in the Public Interest (nyhyzx07-057), the Program for Changjiang Scholars and Innovative Research Team in University (IRT0976), Natural Science Foundation of Chongqing (CSTC, 2009BA1042), and the earmarked fund for Modern Agro-industry (Citrus) Technology Research System of China to JinJun Wang.

\section{Authors' contributions}

MLY designed the experiments, carried out the data analyses and drafted the manuscript, tables and figures. DDW, BJW, and WD participated in the experiments. JJW supervised this study, contributed to the design of the 
study and drafting the manuscript. All authors read and approved the final manuscript.

Received: 20 June 2010 Accepted: 23 October 2010

Published: 23 October 2010

\section{References}

1. Bolland HR, Gutierrez J, Flechtmann CHW: World catalogue of the spider mite family (Acari: Tetranychidae). Leiden: Brill Academic Publishers; 1998.

2. Osakabe M, Uesugi R, Goka K: Evolutionary aspects of acaricide-resistance development in spider mites. Psyche 2009, 11.

3. Van Leeuwen $T$, Vanholme $B$, Van Pottelberge $S$, Van Nieuwenhuyse $P$, Nauen R, Tirry L, Denholm I: Mitochondrial heteroplasmy and the evolution of insecticide resistance: non-Mendelian inheritance in action. Proc Natl Acad Sci USA 2008, 105:5980-5985.

4. Dekeyser MA: Acaricide mode of action. Pest Manage Sci 2005, 61:103-110.

5. Van Pottelberge S, Van Leeuwen T, Nauen R, Tirry L: Resistance mechanisms to mitochondrial electron transport inhibitors in a fieldcollected strain of Tetranychus urticae Koch (Acari: Tetranychidae). Bull Entomol Res 2009, 99:23-31.

6. Boore $J$ : The use of genome-level characters for phylogenetic reconstruction. Trends Ecol Evol 2006, 21:439-446.

7. Dowton M, Castro LR, Austin AD: Mitochondrial gene rearrangements as phylogenetic characters in the invertebrates: the examination of genome 'morphology'. Invertebr Syst 2002, 16:345-356.

8. Masta SE: Mitochondrial rRNA secondary structures and genome arrangements distinguish chelicerates: comparisons with a harvestman (Arachnida: Opiliones: Phalangium opilio). Gene 2010, 449:9-21.

9. Boore JL: Animal mitochondrial genomes. Nucleic Acids Res 1999, 27:1767-1780.

10. Shao RF, Mitani H, Barker SC, Takahashi M, Fukunaga M: Novel mitochondrial gene content and gene arrangement indicate illegitimate inter-mtDNA recombination in the chigger mite, Leptotrombidium pallidum. J Mol Evol 2005, 60:764-773.

11. Jeyaprakash A, Hoy MA: The mitochondrial genome of the predatory mite Metaseiulus occidentalis (Arthropoda: Chelicerata: Acari: Phytoseiidae) is unexpectedly large and contains several novel features. Gene 2007, 391:264-274.

12. Domes K, Maraun M, Scheu S, Cameron SL: The complete mitochondrial genome of the sexual oribatid mite Steganacarus magnus: genome rearrangements and loss of tRNAs. BMC Genomics 2008, 9:532.

13. Shao RF, Barker SC, Mitani H, Takahashi M, Fukunaga M: Molecular mechanisms for the variation of mitochondrial gene content and gene arrangement among chigger mites of the genus Leptotrombidium (Acari: Acariformes). J Mol Evol 2006, 63:251-261.

14. Dermauw W, Van Leeuwen T, Vanholme B, Tirry L: The complete mitochondrial genome of the house dust mite Dermatophagoides pteronyssinus (Trouessart): a novel gene arrangement among arthropods. BMC Genomics 2009, 10:107.

15. Klimov PB, OConnor BM: Improved tRNA prediction in the American house dust mite reveals widespread occurrence of extremely short minimal tRNAs in acariform mites. BMC Genomics 2009, 10:598.

16. Oliveira DC, Raychoudhury R, Lavrov DV, Werren JH: Rapidly evolving mitochondrial genome and directional selection in mitochondrial genes in the parasitic wasp nasonia (hymenoptera: pteromalidae). Mol Biol Evol 2008, 25:2167-2180.

17. Yukuhiro K, Sezutsu H, Itoh M, Shimizu K, Banno Y: Significant levels of sequence divergence and gene rearrangements have occurred between the mitochondrial genomes of the wild mulberry silkmoth, Bombyx mandarina, and its close relative, the domesticated silkmoth, Bombyx mori. Mol Biol Evol 2002, 19:1385-1389.

18. Sheffield NC, Song H, Cameron SL, Whiting MF: A comparative analysis of mitochondrial genomes in Coleoptera (Arthropoda: Insecta) and genome descriptions of six new beetles. Mol Biol Evol 2008, 25:2499-2509.

19. Montooth KL, Abt DN, Hofmann JW, Rand DM: Comparative genomics of Drosophila mtDNA: novel features of conservation and change across functional domains and lineages. J Mol Evol 2009, 69:94-114.

20. Van Leeuwen T, Van Nieuwenhuyse P, Vanholme B, Dermauw W, Nauen R, Tirry L: Parallel evolution of cytochrome $b$ mediated bifenazate resistance in the citrus red mite Panonychus citri. Insect Mol Biol 2010.
21. Park SJ, Lee YS, Hwang UW: The complete mitochondrial genome of the sea spider Achelia bituberculata (Pycnogonida, Ammotheidae): arthropod ground pattern of gene arrangement. BMC Genomics 2007, 8:343.

22. Ma C, Liu C, Yang P, Kang L: The complete mitochondrial genomes of two band-winged grasshoppers, Gastrimargus marmoratus and Oedaleus asiaticus. BMC Genomics 2009, 10:156.

23. Hua J, Li M, Dong P, Cui Y, Xie Q, Bu W: Comparative and phylogenomic studies on the mitochondrial genomes of Pentatomomorpha (Insecta: Hemiptera: Heteroptera). BMC Genomics 2008, 9:610.

24. Oliveira MT, Barau JG, Junqueira AC, Feijao PC, Rosa AC, Abreu CF, AzeredoEspin AM, Lessinger AC: Structure and evolution of the mitochondrial genomes of Haematobia irritans and Stomoxys calcitrans: the Muscidae (Diptera: Calyptratae) perspective. Mol Phylogenet Evol 2008, 48:850-857.

25. Zhang DX, Hewitt GM: Insect mitochondrial control region: A review of its structure, evolution and usefulness in evolutionary studies. Biochem Syst Ecol 1997, 25:99-120.

26. Tsujino F, Kosemura A, Inohira K, Hara T, Otsuka YF, Obara MK, Matsuura ET: Evolution of the $A+T$-rich region of mitochondrial DNA in the melanogaster species subgroup of Drosophila. J Mol Evol 2002, 55:573-583.

27. Oliveira MT, Azeredo-Espin AML, Lessinger AC: The mitochondrial DNA control region of Muscidae flies: evolution and structural conservation in a dipteran context. J Mol Evol 2007, 64:519-527.

28. Saito S, Tamura K, Aotsuka T: Replication origin of mitochondrial DNA in insects. Genetics 2005, 171:1695-1705.

29. Carapelli A, Comandi S, Convey P, Nardi F, Frati F: The complete mitochondrial genome of the Antarctic springtail Cryptopygus antarcticus (Hexapoda: Collembola). BMC Genomics 2008, 9:315.

30. Zhang DX, Szymura JM, Hewitt GM: Evolution and structural conservation of the control region of insect mitochondrial DNA. J Mol Evol 1995, 40:382-391.

31. Black WC, Roehrdanz RL: Mitochondrial gene order is not conserved in arthropods: prostriate and metastriate tick mitochondrial genomes. $\mathrm{Mol}$ Biol Evol 1998, 15:1772-1785.

32. Kilpert F, Podsiadlowski L: The complete mitochondrial genome of the common sea slater, Ligia oceanica (Crustacea, Isopoda) bears a novel gene order and unusual control region features. BMC Genomics 2006, 7:241

33. Fahrein K, Talarico G, Braband A, Podsiadlowski L: The complete mitochondrial genome of Pseudocellus pearsei (Chelicerata: Ricinulei) and a comparison of mitochondrial gene rearrangements in Arachnida. BMC Genomics 2007, 8:386.

34. Lavrov DV, Boore JL, Brown WM: The complete mitochondrial DNA sequence of the horseshoe crab Limulus polyphemus. Mol Biol Evol 2000, 17:813-824.

35. Staton JL, Daehler LL, Brown WM: Mitochondrial gene arrangement of the horseshoe crab Limulus polyphemus L.: conservation of major features among arthropod classes. Mol Biol Evol 1997, 14:867-874.

36. Boore $\lrcorner$, Brown WM: Big trees from little genomes: mitochondrial gene order as a phylogenetic tool. Curr Opin Genet Dev 1998, 8:668-674.

37. Shao R, Aoki Y, Mitani H, Tabuchi N, Barker SC, Fukunaga M: The mitochondrial genomes of soft ticks have an arrangement of genes that has remained unchanged for over 400 million years. Insect Mol Biol 2004, 13:219-224.

38. Hassanin A, Leger N, Deutsch J: Evidence for multiple reversals of asymmetric mutational constraints during the evolution of the mitochondrial genome of Metazoa, and consequences for phylogenetic inferences. Syst Biol 2005, 54:277-298.

39. Hassanin A: Phylogeny of Arthropoda inferred from mitochondrial sequences: Strategies for limiting the misleading effects of multiple changes in pattern and rates of substitution. Mol Phylogenet Evol 2006, 38:100-116.

40. Perna NT, Kocher TD: Patterns of nucleotide composition at fourfold degenerate sites of animal mitochondrial genomes. J Mol Evol 1995, 41:353-358.

41. Podsiadlowski L, Bartolomaeus T: Major rearrangements characterize the mitochondrial genome of the isopod Idotea baltica (Crustacea: Peracarida). Mol Phylogenet Evol 2006, 40:893-899.

42. Qiu Y, Song D, Zhou K, Sun H: The mitochondrial sequences of Heptathela hangzhouensis and Ornithoctonus huwena reveal unique gene arrangements and atypical tRNAs. J Mol Evol 2005, 60:57-71. 
43. Masta SE, Boore JL: The complete mitochondrial genome sequence of the spider Habronattus oregonensis reveals rearranged and extremely truncated tRNAs. Mol Biol Evol 2004, 21:893.

44. Dermauw W, Vanholme B, Tirry L, Van Leeuwen T: Mitochondrial genome analysis of the predatory mite Phytoseiulus persimilis and a revisit of the Metaseiulus occidentalis mitochondrial genome. Genome 2010, 53:285-301.

45. Navajas M, Le Conte Y, Solignac M, Cros-Arteil S, Cornuet JM: The complete sequence of the mitochondrial genome of the honeybee ectoparasite mite Varroa destructor (Acari: Mesostigmata). Mol Biol Evol 2002, 19:2313-2317.

46. Taanman JW: The mitochondrial genome: structure, transcription, translation and replication. Biochim Biophys Acta, Bioenerg 1999, 1410:103-123.

47. Podsiadlowski L, Braband A: The complete mitochondrial genome of the sea spider Nymphon gracile (Arthropoda: Pycnogonida). BMC Genomics 2006, 7:284.

48. Salvato $P$, Simonato $M$, Battisti $A$, Negrisolo $E$ : The complete mitochondrial genome of the bag-shelter moth Ochrogaster lunifer (Lepidoptera, Notodontidae). BMC Genomics 2008, 9:331.

49. Wolstenholme DR: Animal mitochondrial DNA: structure and evolution. Int Rev Cytol 1992, 141:173-216.

50. Ojala D, Montoya J, Attardi G: tRNA punctuation model of RNA processing in human mitochondria. Nature 1981, 290:470-474.

51. Hebert PDN, Ratnasingham S, de Waard JR: Barcoding animal life: cytochrome c oxidase subunit 1 divergences among closely related species. Proc R Soc Lond B 2003, 270:S96-99.

52. Roques S, Fox CJ, Villasana Ml, Rico C: The complete mitochondrial genome of the whiting, Merlangius merlangus and the haddock, Melanogrammus aeglefinus: A detailed genomic comparison among closely related species of the Gadidae family. Gene 2006, 383:12-23.

53. Swafford L, Bond JE: The symbiotic mites of some Appalachian Xystodesmidae (Diplopoda: Polydesmida) and the complete mitochondrial genome sequence of the mite Stylochyrus rarior (Berlese) (Acari: Mesostigmata: Ologamasidae). Invertebr Syst 2009, 23:445-451.

54. Ernsting BR, Edwards DD, Aldred KJ, Fites JS, Neff CR: Mitochondrial genome sequence of Unionicola foili (Acari: Unionicolidae): a unique gene order with implications for phylogenetic inference. Exp Appl Acarol 2009, 49:305-316.

55. Lowe TM, Eddy SR: tRNAscan-SE: A program for improved detection of transfer RNA genes in genomic sequence. Nucleic Acids Res 1997, 25:955-964.

56. Laslett D, Canback B: ARWEN: a program to detect tRNA genes in metazoan mitochondrial nucleotide sequences. Bioinformatics 2008, 24:172-175.

57. Masta SE, Boore JL: Parallel evolution of truncated transfer RNA genes in arachnid mitochondrial genomes. Mol Biol Evol 2008, 25:949-959.

58. Davila S, Pinero D, Bustos P, Cevallos MA, Davila G: The mitochondria genome sequence of the scorpion Centruroides limpidus (Karsch 1879) (Chelicerata; Arachnida). Gene 2005, 360:92-102.

59. Okimoto R, Macfarlane JL, Clary DO, Wolstenholme DR: The mitochondria genomes of two nematodes, Caenorhabditis elegans and Ascaris suum. Genetics 1992, 130:471.

60. Cui P, Ji R, Ding F, Qi D, Gao H, Meng H, Yu J, Hu S, Zhang H: A complete mitochondrial genome sequence of the wild two-humped camel (Camelus bactrianus ferus): an evolutionary history of camelidae. BMC Genomics 2007, 8:241.

61. Lavrov DV, Brown WM, Boore JL: A novel type of RNA editing occurs in the mitochondrial tRNAs of the centipede Lithobius forficatus. Proc Natl Acad Sci USA 2000, 97:13738-13742.

62. Navajas M, Lagnel J, Gutierrez J, Boursot P: Species-wide homogeneity of nuclear ribosomal ITS2 sequences in the spider mite Tetranychus urticae contrasts with extensive mitochondrial COI polymorphism. Heredity 1998, 80:742-752.

63. Hinomoto N, Takafuji A: Genetic diversity and phylogeny of the Kanzawa spider mite, Tetranychus kanzawai, in Japan. Exp Appl Acarol 2001, 25:355-370.

64. Navajas $M$, Boursot P: Nuclear ribosomal DNA monophyly versus mitochondrial DNA polyphyly in two closely related mite species: the influence of life history and molecular drive. Proc R Soc Lond B 2003, 270 : S124-S127.
65. Pons J: DNA-based identification of preys from non-destructive, total DNA extractions of predators using arthropod universal primers. $\mathrm{Mol}$ Ecol Notes 2006, 6:623-626.

66. Larkin MA, Blackshields G, Brown NP, Chenna R, McGettigan PA, McWilliam H, Valentin F, Wallace IM, Wilm A, Lopez $\mathrm{R}$, Thompson JD, Gibson TJ, Higgins DG: Clustal W and Clustal X version 2.0. Bioinformatics 2007, 23:2947-2948.

67. Zuker M: Mfold web server for nucleic acid folding and hybridization prediction. Nucleic Acids Res 2003, 31:3406-3415.

68. Tamura K, Dudley J, Nei M, Kumar S: MEGA4: molecular evolutionary genetics analysis (MEGA) software version 4.0. Mol Biol Evol 2007, 24:1596-1599.

69. Xia X, Xie Z: DAMBE: software package for data analysis in molecular biology and evolution. J Hered 2001, 92:371-373.

70. Nei M, Kumar S: Molecular evolution and phylogenetics. New York: Oxford University Press; 2000

71. Posada D: jModelTest: phylogenetic model averaging. Mol Biol Evol 2008, 25:1253-1256.

72. De Rijk P, Robbrecht E, dex Hoog S, Caers A, Van de Peer Y, De Wachter R: Database on the structure of large subunit ribosomal RNA. Nucleic Acids Res 1999, 27:174-178

73. Van de Peer $Y$, Caers A, De Rijk P, De Wachter R: Database on the structure of small ribosomal subunit RNA. Nucleic Acids Res 1998, 26:179-182.

doi:10.1186/1471-2164-11-597

Cite this article as: Yuan et al:: The complete mitochondrial genome of the citrus red mite Panonychus citri (Acari: Tetranychidae): high genome rearrangement and extremely truncated tRNAs. BMC Genomics 2010 11:597

\section{Submit your next manuscript to BioMed Central and take full advantage of:}

- Convenient online submission

- Thorough peer review

- No space constraints or color figure charges

- Immediate publication on acceptance

- Inclusion in PubMed, CAS, Scopus and Google Scholar

- Research which is freely available for redistribution 